\title{
Evaluasi Kualitas Hasil Praktek Las Busur Guna Menunjang Kerja Di Kapal
}

\author{
Prasetya Sigit Santosa ${ }^{{ }^{*}}$ \\ ${ }^{1}$ Akademi Maritim Yogyakarta,Jl.Magelang Km 4,4, Yogyakarta 55284, Indonesia, \\ *Corresponding Author. E-mail : sigitamy65@ gmail.com.Telp. 0818270011
}

\begin{abstract}
Abstrak
Penelitian terhadap benda hasil praktek taruna, pada umumnya dilakukan secara visual, termasuk hasil praktek las busur taruna Jurusan Teknika Akademi Maritim Yogyakarta, karena metode tersebut yang dianggap paling praktis, akan tetapi metode tersebut belum bisa mengungkap kualitas hasil praktek, terutama berhubungan dengan sifat mekanis dan deposit logam. Sehubungan dengan hal tersebut, penelitian ini untuk mengetahui kualitas hasil praktek las busur,dengan melakukan pengujian tarik dan pengujian makro. Penelitian ini merupakan penelitian deskriptif dengan populasi penelitian 40 benda hasil praktek las busur taruna, dan sampel penelitian $50 \%$ dari populasi. Kelulusan pengujian tarik, ditentukan dengan membandingkan data tegangan Tarik. Minimum bahan dasar dan bahan las. Sedangkan kelulusan uji makro ditentukan dengan ada tidaknya cacat di dalam deposit logam. Jumlah kelulusan dari kedua pengujian tersebut diprosentasekan. Dalam penelitian ini taruna dapat melakukan pengelasan sambungan I dengan hasil memenuhi syarat kelulusan uji tarik berjumlah 12 taruna atau ( $60 \%$ ), sedangkan taruna yang dapat melakukan pengelasan sambungan I dan $\mathrm{T}$ dengan hasil memenuhi syarat kelulusan uji makro, adalah untuk sambungan I sebanyak 16 buah (70\%), sedangkan sambungan T sebesar $65 \%$.
\end{abstract}

Kata Kunci : Pengujian tarik dan makro

\begin{abstract}
Research on cadets practicing objects is generally done visually, including the results of the practice of cadet welding at the Yogyakarta Maritime Academy, because the method is considered the most practical, but the method has not been able to reveal the quality of the results of the practice, especially related to mechanical properties and metal deposit. In connection with this, this study is to determine the quality of the results of the practice of arc welding, by doing tensile testing and macro testing. This research is a descriptive study with a research population of 40 objects from the practice of cadet arc welding, and a research sample of 50\% of the population. Graduation of tensile testing, determined by comparing the tensile stress data. Minimum basic materials and welding materials. While the graduation of the macro test is determined by the presence or absence of defects in the metal deposit. The number of graduations from the two tests is published. In this study cadets can do the welding I connection with the results of fulfilling the graduation test requirement of 12 cadets or (60\%), while cadets who can do welding I and $T$ connections with the results of fulfilling the macro test graduation requirements, are as many as I connections 16 pieces (70\%), while the T connection is $65 \%$.
\end{abstract}


Keywords: Tensile and Macro Testing

\section{PENDAHULUAN}

Pendidikan profesional merupakan pendidikan tinggi yang diarahkan pada kesiapan penerapan keahlian tertentu. Pendidikan Kepelautan merupakan salah satu Program pendidikan yang dilaksanakan sesuai kurikulum yang disusun oleh akademi mengacu pada kurikulum nasional dan panduan kurikulum STCW '95, sesuai dengan perkembangan dunia ilmu pengetahuan, teknologi dan/atau kesenian serta kebutuhan masyarakat sesuai dengan pola ilmiah pokok. Kurikulum mata kuliah yang secara potensial diharapkan akan dapat menghasilkan lulusan sesuai ciri -ciri khas dalam ruang lingkup program studi yang berkaitan dengan sebutan professional.

Mata Kuliah Kerja Bengkel salah satunya adalah Praktek Las di Akademi Maritim Yogyakarta merupakan mata kuliah dasar keahlian, yang harus ditempuh oleh semua mahasiswa semester III dan IV dengan bobot sks 6 pada Jurusan Teknika Mesin Kapal. Mata kuliah ini diujikan baik program diploma III maupun Profesi. Dengan pembagian tersebut diharapkan mahasiswa menguasai bidangbidang teknologi sesuai dengan spesifikasinya untuk bekal setelah lulus nantinya.

Untuk mengetahui apakah mahasiswa benar-benar menguasai bidangnya diperlukan suatu alat evaluasi yang handal, karena alat evaluasi tersebut harus benar-benar dapat mengungkap apakah hasil praktek mahasiswa sudah memenuhi kriteria atau belum. Dalam melakukan evaluasi yang baik, pihak perguruan tinggi khususnya jurusan Teknik Mesin Kapal cukup kesulitan dalam hal evaluasi yang digunakan untuk mengevaluasi hasil praktek pengelasan.

Biasanya selama ini evaluasi hasil praktek las busur mahasiswa hanya dilakukan pengamatan secara visual. Hal ini dilakukan karena metode penilaian tersebut paling murah dan praktis. Namun metode penilaian ini belum menjamin baik tidaknya kualitas hasil pengelasan yang sebenarnya. Untuk mengetahui kualitas hasil pengelasan harus dilakukan dengan pengujian, yaitu dengan menggunakan metode peralatan yang telah di persyaratkan.

Sehubungan dengan hal tersebut, perlu diadakan penelitian untuk mengungkap kualitas hasil praktek las busur mahasiswa jurusan teknik kapal Akademi Maritim Yogyakarta dengan menggunakan prosedur yang benar yang telah dipersyaratkan. Sehingga diharapkan hasil penelitian ini dapat memberikan masukan pada jurusan teknik mesin kapal agar ketrampilan las busur mahasiswanya dapat ditingkatkan dan hasilnya memenuhi standar pengelasan.

Sampai saat ini evaluasi hasil praktek las busur mahasiswa jurusan teknik mesin kapal belum dapat dijadikan tolok ukur kualitas hasil las yang sebenarnya. Untuk mengetahui kualitas hasil las busur yang sebenarnya harus dilakukan pengujian. Dengan harapan dengan pengujian ini dapat diketahui cacat-cacat las busur yang berupa porositas, kotoran, cacat penetrasi, dan kekuatan tarik sambungan las dari hasil praktek las busur mahasiswa semester III dan IV jurusan teknik mesin kapal Akademi Maritim Yogyakarta.

Ada beberapa macam metode pengujian las busur, namun mengingat terbatasnya waktu dan sarana yang ada di laboratorium bahan maka, kualitas las busur hasil praktek mahasiswa semester III, yang diungkap hanya berdasarkan 
pengujian tarik dan makro. Rumusan masalahnya yaitu bagaimana kualitas las busur hasil praktek mahasiswa Teknik Mesin Kapal Semester IV Akademi Maritim Yogyakarta bila ditinjau dengan pengujian Tarik dan Makro.

Untuk mengetahui kualitas las busur pada hasil praktek mahasiswa semester III jurusan teknik Akademi Maritim Yogyakarta dengan menggunakan pengujian tarik dan makro. Dengan demikian diharapkan sasaran perkuliahan mahasiswa dapat tercapai.

Diharapkan penelitian ini dapat memberikan masukan yang bermakna pada jurusan teknik mesin kapal dalam menentukan strategi pengajaran yang tepat agar kualitas lulusan dapat meningkat sesuai kebutuhan didunia kepelautan di masa sekarang.

\section{Pengujian Bahan}

Dalam proses belajar las busur indicator kebehasilannya dapat dilihat dari kemampuan mahasiswa dalam memahami teori, melakukan proses pengelasan dengan benar dan dapat memenuhi standar las, khususnya untuk las busur.

Dalam mengungkapkan kemampuan mahasiswa dalam memahami teori dapat diungkap dengan menggunakan tes tertulis, adapun dalam mengungkap proses pengelasan dengan menggunakan tes performance. Untuk mengetahui keberhasilan mahasiswa dalam memenuhi standar las diperlukan pengujian.

Menurut Bristish Standart, dalam melakukan penilaian sambungan las busur, disebutkan faktor-faktor yang harus dipertimbangkan, hal ini dikemukakan oleh Smith (1981-298), sebagai berikut:

Referring to this standart, some of the main factors to be considered when making assessment of weld quality are :

Shape of profile

1.2. Uniformity of surface

1.3. Degree of andercut

1.4. Smoothness of joint where weld is recommended

Freedom from surface defects

Penetrasition bead

Degree of fusion

Degree of root penetration

Non metallic inclusions and gas cavities

Untuk mengetahui faktor-faktor tersebut memenuhi syarat atau tidak diperlukan pengujian-pengujian.

Sedangkan menurut Sriwidharto (1987:64). Pengujian las busur terdiri atas dua kategori, yaitu pengujian secara distructive Test (Pengujian dengan merusak) dan pengujian secara non distructive Test (Pengujian dengan tidak merusak benda kerja).

\section{Pengujian Tarik}

Pengujian tarik sambungan las juga dapat digunakan untuk mengetahui kekuatan tarik dan sifat elastisitas bahan, dan juga untuk mengetahui apakah bahan memenuhi syarat dapat digunakan atau tidak. Menurut pendapat Sriwidharto adalah sebagai berikut: Kekuatan tarik dapat diketahui dengan memberikan beban 
tarik pada benda uji sampai putus. Kemudian membagi beban maksimum dengan luas penampang terkecil benda uji tersebut. (1987:76).

Sedangkan untuk menentukan elastisitas bahan dengan mengetahui dari penambahan panjang benda uji, bila memenuhi syarat kelulusan uji tarik, maka benda uji tersebut memenuhi syarat dapat dipergunakan.

Kriteria benda uji yang dapat memenuhi lulus uji tarik jika kekuatan tariknya tidak kurang dari:

2.1 Kuat Tarik minimum yang ditentukan dari bahan dasar.

2.2 Kekuatan tarikan minim ditentukan dari bahan yang terlemah, jika digunakan beberapa bahan yang berbeda kuat tarik minimumnya.

2.3 Kuat tarik minimum yang ditentukan dari bahan las apabila bahan las tersebut memiliki kuat tarik lebih rendah dari bahan dasar.

Apabila benda uji putus pada bahan dasar diluar sambungan las atau diluar garis fusi, pengujian dinyatakan memenuhi syarat, asalkan kekuatan tariknya tidak melebihi 5\% dibawah kuat tarik minimum yang ditentukan dari bahan dasar (Sriwidharto 1987:77).

Dalam pengujian tarik ini, bentuk benda uji dan ukurannya harus memenuhi standar tertentu yang telah ditentukan salah satunya adalah:Bentuk dan ukuran benda uji tarik dilihat dibawah ini.

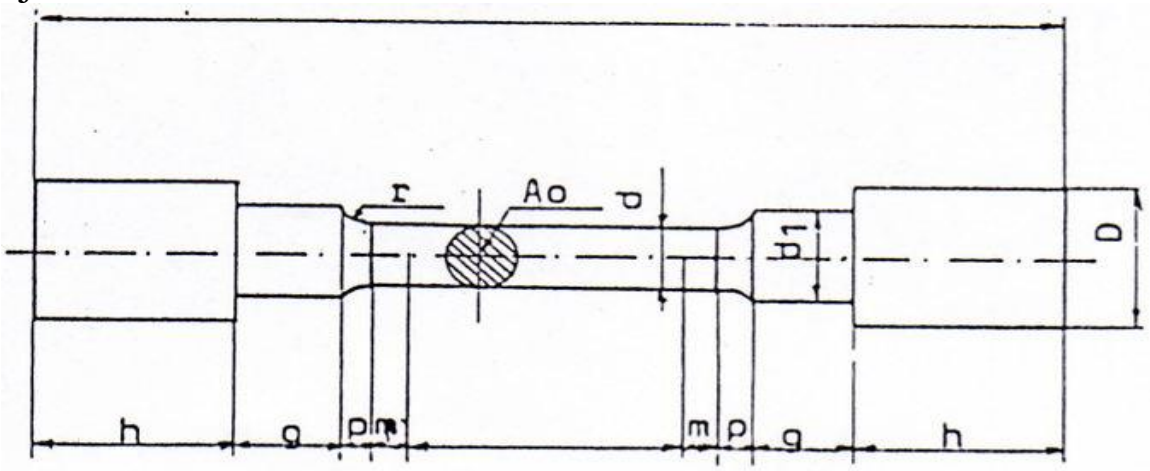

Gambar 1. Penampang benda uji Turned Speciment (Grenendijk,1984:18)

Gambar diatas menunjukkan bentuk benda uji turned speciment yang harus diterapkan pada uji tarik, untuk ukurannya dapat dilihat pada tabel dibawah ini.

Tabel 1: Normalisasi Benda Uji Turned Specimen

\begin{tabular}{|c|c|c|c|c|c|c|c|c|c|c|c|c|c|}
\hline D & dl & $\begin{array}{c}\text { D } \\
\text { Min }\end{array}$ & $\begin{array}{c}\text { g } \\
\text { Min }\end{array}$ & Min & m & P & r & \multicolumn{3}{|c|}{ Batang uji dapat 5 } & \multicolumn{3}{|c|}{ Batang uji dapat 10 } \\
\hline 6 & 7,5 & 11 & 6 & 11 & 3 & 2 & 3 & 30 & 36 & 74 & 60 & 66 & 101 \\
\hline 8 & 10 & 14 & 8 & 13 & 4 & 3 & 4 & 40 & 48 & 96 & 80 & 88 & 136 \\
\hline 10 & 12 & 18 & 10 & 15 & 5 & 3 & 5 & 50 & 60 & 116 & 100 & 110 & 166 \\
\hline 12 & 14,5 & 21 & 12 & 17 & 6 & 4 & 6 & 60 & 72 & 138 & 120 & 132 & 198 \\
\hline 14 & 17 & 25 & 14 & 19 & 7 & 4,5 & 7 & 70 & 84 & 159 & 140 & 154 & 229 \\
\hline 16 & 19 & 28 & 16 & 21 & 8 & 5 & 8 & 80 & 96 & 180 & 160 & 176 & 260 \\
\hline 18 & 22 & 31 & 18 & 23 & 9 & 6 & 9 & 90 & 108 & 202 & 180 & 198 & 292 \\
\hline 20 & 24 & 35 & 20 & 25 & 10 & 6 & 10 & 100 & 120 & 222 & 200 & 220 & 322 \\
\hline 25 & 30 & 44 & 25 & 30 & 13,5 & 7,5 & 12,5 & 125 & 150 & 275 & 250 & 275 & 400 \\
\hline
\end{tabular}


Ukuran dalam satuan mm (mili meter)

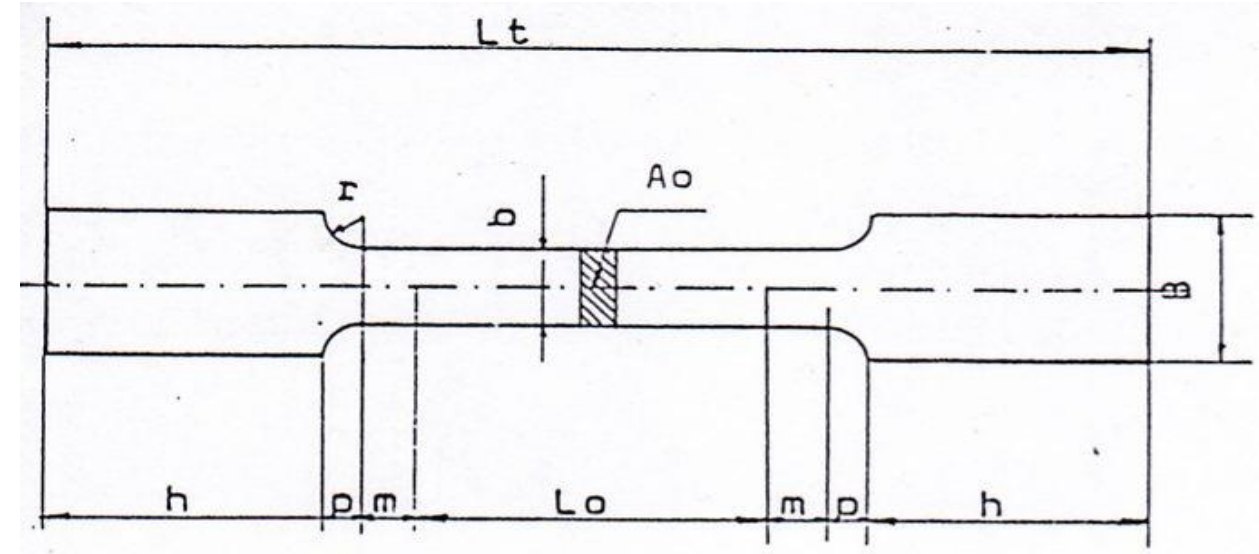

(Groendijk, 1984:20)

Gambar 2. Penampang Benda Uji Reduced Section

Gambar diatas menunjukkan benda uji reduced section, ukurannya dapat terlihat pada tabel 2 .

Tabel 2 : Normalisasi Benda Uji Turned Specimen

\begin{tabular}{|c|c|c|c|c|c|c|c|c|c|c|c|c|c|c|}
\hline \multirow[t]{2}{*}{ A } & \multirow[t]{2}{*}{$\mathrm{b}$} & \multirow[t]{2}{*}{$\begin{array}{l}\text { Ao } \\
\mathrm{mm}^{2}\end{array}$} & \multirow{2}{*}{\multicolumn{2}{|c|}{ B }} & \multirow[t]{2}{*}{$\begin{array}{c}\mathrm{h} \\
\text { Min }\end{array}$} & \multirow[t]{2}{*}{$\mathrm{m}$} & \multirow[t]{2}{*}{$\mathrm{P}$} & \multirow[t]{2}{*}{$\mathrm{r}$} & \multicolumn{3}{|c|}{ Batang uji dapat 5} & \multicolumn{3}{|c|}{$\begin{array}{c}\text { Batang uji dapat } \\
10 \\
\end{array}$} \\
\hline & & & & & & & & & Lo & $\begin{array}{c}\mathrm{Lo}+2 \\
2 \mathrm{~m}\end{array}$ & $\begin{array}{c}\mathrm{Lt} \\
\text { min }\end{array}$ & Lo & $\begin{array}{l}\mathrm{Lo}+2 \\
+2 \mathrm{~m} \\
\end{array}$ & $\begin{array}{c}\mathrm{Lt} \\
\mathrm{min}\end{array}$ \\
\hline 5 & 10 & 50 & 16 & M15 & 20 & 4 & 5,5 & 8 & 40 & 48 & 121 & 80 & 88 & 161 \\
\hline 5 & 16 & 80 & 22 & M22 & 30 & 5 & 7 & 10 & 50,5 & 60.5 & 139,5 & 101 & 111 & 185 \\
\hline 6 & 20 & 120 & 27 & M27 & 40 & 6,5 & 8,5 & 12 & 62 & 75 & 172 & 124 & 137 & 234 \\
\hline 7 & 22 & 154 & 27 & M27 & 45 & 7 & 9 & 14 & 70 & 84 & 190 & 140 & 154 & 260 \\
\hline 8 & 25 & 200 & 33 & M33 & 50 & 8 & 10 & 16 & 80 & 96 & 216 & 160 & 176 & 296 \\
\hline 10 & 25 & 250 & 33 & M33 & 60 & 9 & 11,5 & 18 & 89,5 & 107,5 & 250 & 180 & 197 & 330 \\
\hline 10 & 31 & 310 & 40 & - & 70 & 10 & 12,5 & 20 & 100 & 119,5 & 284,5 & 199 & 219 & 384 \\
\hline 12 & 26 & 312 & 33 & M33 & 70 & 10 & 11,5 & 20 & 100 & 120 & 288 & 200 & 220 & 388 \\
\hline 15 & 30 & 450 & 40 & - & 70 & 12 & 14,5 & 24 & 120 & 144 & 313 & 240 & 264 & 435 \\
\hline 18 & 30 & 540 & 40 & - & 70 & 13,5 & 16 & 27 & 131 & 158,5 & 330,5 & 263 & 290 & 462 \\
\hline 22 & 30 & 660 & 40 & - & 80 & 14,5 & 16,5 & 29 & 145 & 174 & 367 & 290 & 319 & 512 \\
\hline 24 & 30 & 720 & 40 & - & 80 & 15,5 & 17 & 31 & 151 & 180,5 & 374,5 & 301 & 331 & 525 \\
\hline
\end{tabular}

Ukuran dalam memiliki (mili meter)

Standarisasi bentuk dan ukuran benda uji dapat juga dilakukan tanpa mengikuti prosedur yang disebutkan terdahulu. Ada prosedur lain yang lebih praktis dan mudah diikuti, karena luas penampang ditentukan sendiri oleh peneliti. Sehingga prosedur ini dapat diterapkan pada pengujian sambungan las berbagai macam ukurannya. 

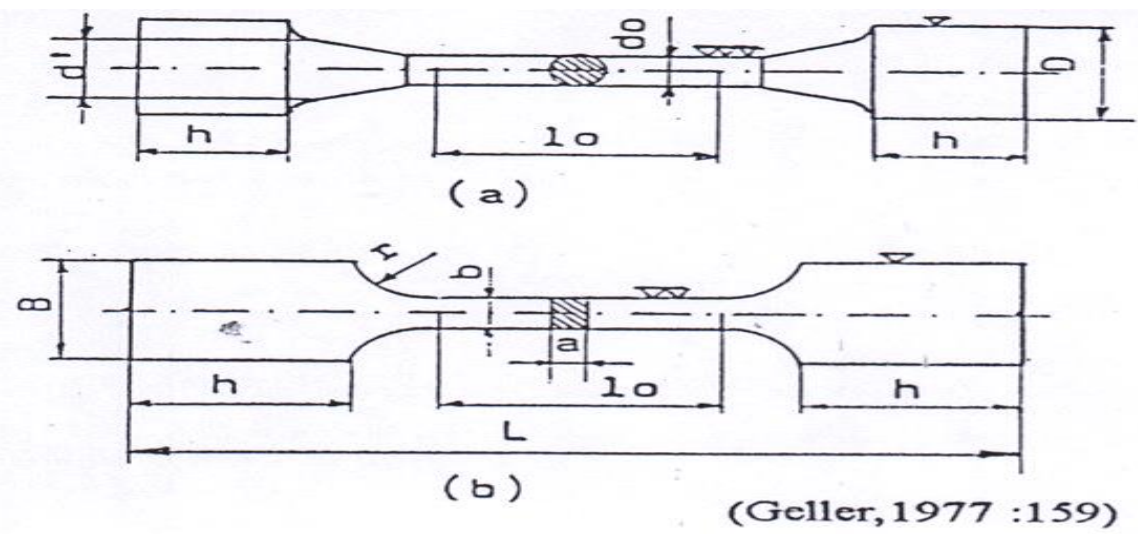

Gambar 3. Standard Specimens for Tensile test

Gambar tersebut di atas menunjukkan normalisasi benda uji tarik benda uji tarik bentuk silinder dan persegi, sedangkan ukurannya yaitu tabel 3 di bawah ini.

Tabel 3. Standard Speciments for Tensile Test

\begin{tabular}{|c|c|c|c|c|}
\hline Specimen & $\begin{array}{c}\text { Gauge Length } \\
\text { Lo } \mathrm{mm}\end{array}$ & $\begin{array}{c}\text { Cross Secsional } \\
\text { Area } \mathrm{mm}^{2}\end{array}$ & $\begin{array}{c}\text { Diameter of } \\
\text { Cylindrical } \\
\text { Specimen do } \\
\text { mm }\end{array}$ & $\begin{array}{c}\text { Symbols to } \\
\text { denote relative } \\
\text { elongation }\end{array}$ \\
\hline Normal Long & 200 & 314 & 20 & $\alpha 10$ \\
Short & 100 & 314 & 20 & $\alpha 15$ \\
Proporsional & $11,3 \sqrt{\mathrm{Fo}}$ & Arbitrary & Arbitrary & $\alpha 10$ \\
Long & $5,65 \sqrt{\mathrm{Fo}}$ & Same & Same & $\alpha 5$ \\
Short & & & & \\
\hline
\end{tabular}

Ditinjau dari jumlahnya benda uji tarik untuk plat terdiri dari uji tunggal dan uji jamak. Menurut pendapat Sriwidharto (1987:75) mengatakan : benda uji tunggal mewakili lokasi tertentu, dan uji jamak dalam satu set terdiri dari beberapa benda uji yang semuanya harus diuji tarik. Setiap set harus mewakili satu macam uji tarik tunggal.

Pengujian tarik tersebut bertujuan dapat mengetahui kekuatannya dari tarikan benda uji, namun belum bisa melihat deposit logam dalam sambugnan las busur. Untuk dapat melihat deposit logam diperlukan suatu pengujian yang bisa melihat bagian dalam sambungan las, salah satu pengujian yang paling murah untuk keperluan tersebut adalah uji makro.

\section{Pengujian Makro}

Uji makro dilakukan dengan mengikis permukaan benda kerja dengan larutan kimia sehingga terlihat struktur makro permukaan benda uji tersebut (Groendijk, 1984:58). Menurut Smith (1981:302) larutan kimia yang digunakan adalah 10-15 ml Nitric Acid (Asam Nitrat) (Specific gravity 1,42), $90 \mathrm{ml}$ Alchohol (Industrial Spirit). Asam Nitrat digunakan untuk pengikisan pemukaan benda uji, sebagian alkhohol digunakan untuk membersihkan benda uji larutan kimia tersebut. 
Uji makro dapat memberikan informasi cacat-cacat bawaan sambungan las yang berupa:

1. Incorrect profile

2. Undercutting

3. Slag Inclusions

4. Porocity and crack

Poor root penetration and lack of fusioan (Smith, 1981:302)

Berikut ini dipresentasikan benda uji makro sebelum dan sesudah diberi larutan kimia.
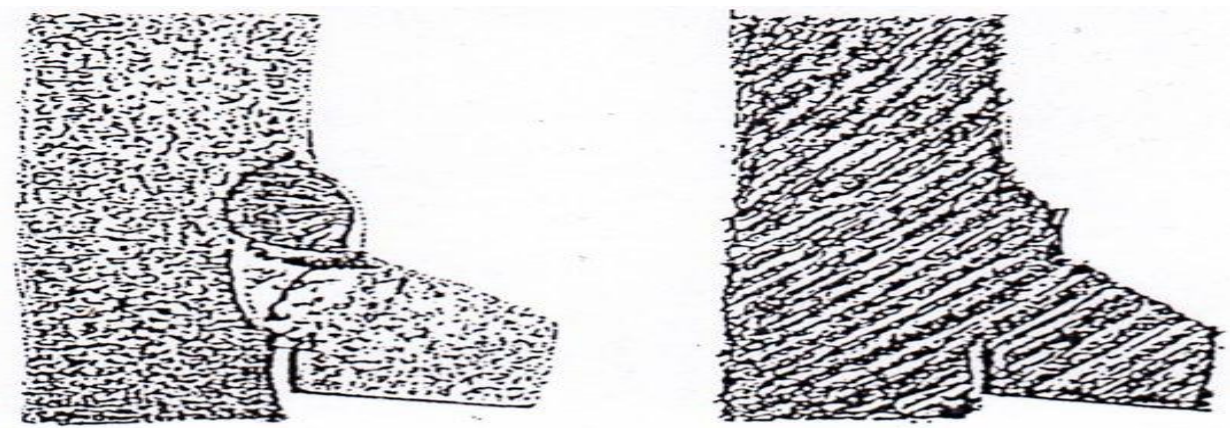

Gambar 4. Benda Uji sebelum dan sesudah di beri larutan kimia

Gambar tersebut diatas menunjukkan adanya porositas pada titik sambungan las busur antara bahan dasar dan bahan tambah. Bagian gelap pada bahan dasar menunjukkan bahwa bagian tersebut telah diperkaya dengan unsur karbon, belerang, dan pospor (Afanasyev, 1977:23).

\section{METODE}

\section{Populasi dan Sampel}

Penelitian diskriptip ini dengan mengambil Populasi mahasiswa semester IV Tahun Akademiki 2017-2018 jurusan Teknika Akademi Maritim Yogyakarta.

Sedangkan sample penelitian ini diambil 20 mahasiswa yang telah melaksanakan praktek las busur. Benda kerja tersebut ada dua macam yaitu sambungan I dan sambungan $\mathrm{T}$ yang masing-masing jenis sambungan berjumlah 20 benda kerja.

\section{Metode Pengambilan Data}

\section{Pengambilan Data untuk Uji Tarik}

Data yang didapat dalam pengujian tarik berupaya gaya tarik dan luas penampangnya. Kedua data tersebut kemudian ditabulasikan dengan membagi gaya tarik dengan luas penampangnya terkecil pada benda uji, akan didapat tegangan tarik minimum benda uji tersebut.

Data kelulusan benda uji terhadap syarat-syarat uji tarik didapat dengan membandingkan tegangan tarik minimum benda uji dengan tegangan tarik minimum bahan dasar dan electrode las busur. 


\section{Pengambilan Data untuk Uji Makro}

Dalam pengujian makro ini, data yang diambil hanya menunjukan ada tidaknya cacat-cacat sambungan las. Jadi belum sampai pada tingkat kecacatannya. Data dicatat dengan memberi tanda pada daftar cacat las sesuai dengan kondisi masing-masing benda uji. Data kelulusan benda uji dicari dengan melihat ada tidaknya cacat pada benda uji tersebut .

\section{Rancangan Penelitian}

\section{Metode Uji Tarik}

Metode pengujian uji tarik terdiri dari:

1. Membentuk benda uji dengan bentuk dan dimensi yang disyaratkan.

2. Menentukan kekuatan bahan dasar dengan kekuatan tarik minimum sebesar $598,40 \mathrm{~N} / \mathrm{mm}^{2}$.

3. Jenis electrode dengan standart ASTM E6013

4. Instrumen uji tarik dengan menggunakan alat universal tensile tester dan jangka sorong.

\section{Metode Pengujian Makro}

1. Membentuk Benda Uji yang disyaratkan.

2. .Instrumen uji makro dengan menggunakan checklist.

\section{Teknik Analisa Data}

Penelitian ini jenisnya penelitian deskriptip dengan menggunakan teknik presentase untuk menganalisis datanya. Dari teknik ini dapat diketahui berapa persen benda uji yang lulus uji tarik. Dengan teknik ini juga dapat diketahui berapa persen benda uji yang mengalami cacat las.

\section{HASIL DAN PEMBAHASAN}

Sebagaimana telah diuraikan padabab sebelumnya, bahwa penelitian ini adalah pengujian hasil praktek las busur jenis sambunga I dan $\mathrm{T}$, bagi Taruna Jurusan Teknika Akademi Maritim Yogyakarta, dilakukan dalam waktu kurang lebih enam bulan. Adapun pengujian yangdilakukan adalah pengujian tarik dan makro.

\section{Hasil Uji Tarik}

Pengujian tarik specimen hanya dilakukan untuk jenis sambungan I. Hasil uji tarik berupa tegangan tarik minimum benda uji sambungan I, tegangan tarik minimum bahan dasar ( plat), dan bahan las. Hasil uji tarik di tabel 4.

Tabel.4. Tegangan tarik minimum specimen, bahan dasar dan bahan las.

\begin{tabular}{|c|l|l|l|}
\hline \multirow{2}{*}{ No } & \multirow{2}{*}{ Sambungan I } & \multicolumn{2}{c|}{ Tegangan Tarik Minimum ( N/mm2) } \\
\cline { 3 - 4 } & & & Teg.Min.Bahan Dasar \\
\hline 1 & 298,02 & & \\
\hline 2 & 370,411 & & 414 \\
\hline 3 & $307,82^{*}$ & 362,82 & \\
\hline 4 & $367,87 \mathrm{~L}$ & & \\
\hline 5 & $450,85 \mathrm{~L}$ & & \\
\hline
\end{tabular}

Majalah Ilmiah Bahari Jogja 15 | http://jurnal.amy.ac.id/index.php/MIBJ/ 


\begin{tabular}{|c|l|l|l|}
\hline 6 & 171,93 & & \\
\hline 7 & 121,36 & & \\
\hline 8 & $329,02^{*}$ & & \\
\hline 9 & $380,71 \mathrm{~L}$ & & \\
\hline 10 & $390,49 \mathrm{~L}$ & & \\
\hline 11 & $151,28^{*}$ & & \\
\hline 12 & $480,77 \mathrm{~L}$ & & \\
\hline 13 & 262,36 & & \\
\hline 14 & $602,43 \mathrm{~L}$ & & \\
\hline 15 & $548,51 \mathrm{~L}$ & & \\
\hline 16 & $368,45 \mathrm{~L}$ & & \\
\hline 17 & $366,45 \mathrm{~L}$ & & \\
\hline 18 & 219,50 & & \\
\hline 19 & $369,56 \mathrm{~L}$ & & \\
\hline 20 & $365,11 \mathrm{~L}$ & & \\
\hline $\begin{array}{l}\text { Jml } \\
\text { Lulus }\end{array}$ & 12 & & \\
\hline
\end{tabular}

Keterangan :

Hasil pengukuran tegangan tarik minimum bahan baja dasar sambungan las sebesar $=362,82 \mathrm{~N} / \mathrm{mm} 2, *=$ Specimen putus di luar garis fusi, $\mathrm{L}=$ Specimen lulus uji tarik

Dengan melihat tabel 4, data yang diperoleh dari uji tarik benda uji sambungan las dibanding dengan kuat tarik minimum bahan dasr dan bahan las. Dari perbandingan tersebut, maka dari jumlah sampel hasil praktek kerja las jenis sambungan I sebanyak 20 buahspecimen, yang memenuhi persyaratan kelulusan uji tarik ada 12 buah, yaitu nomer 2,4,5,9,10,12,14,15,16,17,19 dan 20. Dari jumlah yang memenuhi persyaratan kelulusan, bila diprosentase menjadi sebesar $60 \%$. Ini menggambarkan taruna dalam melakukan pengelasan dengan hasil yang memenuhi persyaratan kelulusan uji tariklebih dari cukup. Namun demikian itu ada fenomena yang menarik, bahwa ada tiga sambungan las yang putus diluar garis fusi dan masih belum dapat memenuhi syarat kelulusan uji tarik.Menurut ketentuan, kriteria pada pengujian tarik benda uji yang putus diluar garis fusi, dapat diasumsikan memenuhi syarat, karena kuat tarik minimum deposit logam sudah melampaui kuat tarik minimum bahan las, akan tetapi bahan uji tersebut masih belum memenuhi syarat kelulusan pada kondisi putus di luar garis fusi, karena kuat tarik minimumnya jauh dibawah kuat tarik minimum bahan dasar. Jumlah specimen yang putus di luar garis fusi berjumlah tiga buah, bila diprosentasekan sebesar $15 \%$ sesuai tabel 3 : Data pengujian tarik sambungan I. Hal yang dapat menyebabkan kejadian tersebut adalah pengaruh panas terhadap benda kerja selama proses pengelasan. Benda kerja akan merubah struktur logamnya, bila dikenai panas dengan jumlah dan lamawaktu tertentu. Bila taruna belum terampil melakukan pengelasan, kemungkinan disebabkan jumlah panas dan lamanya proses pengelasan yang masih belum tepat.Permasalahan inilah yang perlu diungkap lebih lanjut dalam penelitian selanjutnya. 


\section{Hasil Uji Makro}

Hasil pengujian makro dilakukan untuk jenis sambungan I dan T. Hasil pengujian makro yang ada di tabel 6. Dari tabel tersebut menunjukkan bahwa specimen yang memenuhi persyaratan lulus uji makro, jenis sambungan I sebesar $70 \%$, sedangkan untuk jenis sambungan $\mathrm{T}$ sebesar $65 \%$. Dari data diatas, menunjukkan bahwa taruna yang memenuhi persyaratan kelulusan uji makro, lebih besar jika dibandingkan dengan yang memenuhi persyaratan kelulusan uji tarik. Dengan demikian dapat dikatakan, bahwa masih terdapat sebagian taruna yang melakukan pengelasan dengan hasil memenuhi syarat kelulusan uji makro, akan tetapi belum bisa memenuhi persyaratan kelulusan uji tariknya sebesar $25 \%$.

Tabel 5. Data Pengujian Tarik Sambungan I

\begin{tabular}{|l|l|l|l|l|l|l|}
\hline $\begin{array}{l}\text { No. } \\
\text { Spec. }\end{array}$ & $\begin{array}{l}\text { Tebal } \\
(\mathrm{mm})\end{array}$ & $\begin{array}{l}\text { Lebar } \\
(\mathrm{mm})\end{array}$ & $\begin{array}{l}\text { Lo } \\
(\mathrm{mm})\end{array}$ & $\begin{array}{l}\text { Ao } \\
(\mathrm{mm})\end{array}$ & $\begin{array}{l}\text { P.min } \\
(\mathrm{N})\end{array}$ & $\begin{array}{l}\text { St.min } \\
(\mathrm{N} / \mathrm{mm} 2)\end{array}$ \\
\hline 1 & 2 & 10 & 70 & 20 & 6079,72 & 298,02 \\
\hline 2 & 2 & 10 & 70 & 14 & 4461,73 & 309,42 \\
\hline 3 & 2 & 10 & 70 & 15 & 4755,91 & 307,82 \\
\hline 4 & 2 & 10 & 70 & 20 & 7354,50 & 367,87 \\
\hline 5 & 2 & 10 & 70 & 20 & 1296,30 & 450,85 \\
\hline 6 & 2 & 10 & 70 & 18 & 3039,86 & 171,93 \\
\hline 7 & 2 & 10 & 70 & 16 & 1961,20 & 121,36 \\
\hline 8 & 2 & 10 & 70 & 18 & 5881,66 & 329,02 \\
\hline 9 & 2 & 10 & 70 & 19 & 6079,72 & 313,71 \\
\hline 10 & 2 & 10 & 70 & 16 & 5687,48 & 348,49 \\
\hline 11 & 2 & 10 & 70 & 20 & 3334,04 & 151,28 \\
\hline 12 & 2 & 10 & 70 & 20 & 9904,06 & 480,77 \\
\hline 13 & 2 & 10 & 70 & 20 & 6275,84 & 262,36 \\
\hline 14 & 2 & 10 & 70 & 20 & 13532,24 & 602,36 \\
\hline 15 & 2 & 10 & 70 & 19 & 10198,16 & 548,51 \\
\hline 16 & 2 & 10 & 70 & 20 & 4412,70 & 218,89 \\
\hline 17 & 2 & 10 & 70 & 20 & 3530,16 & 185,45 \\
\hline 18 & 2 & 10 & 70 & 20 & 5099,12 & 219,50 \\
\hline 19 & 2 & 10 & 70 & 20 & 5344,27 & 264,56 \\
\hline 20 & 2 & 10 & 70 & 20 & 7746,74 & 365,11 \\
\hline
\end{tabular}

Hal tersebut bisa terjadi, karena masing-masing jenis pengujian sambungan las mempunyai tujuan yang berbeda. Uji tarik untuk mengetahui sifat mekanisbahan, sehingga pengujian diperlukan untuk mengetahui kekuatan sambungan terutama kekuatan tarik. Sedangkan pengujian makro ini akan diketahui kualitas deposit logam sambungan las, sehingga pengujian ini bertujuan untuk mengetahui tingkat kerapatan sambungan las.

Tabel 6. Hasil Pungujian Makro

\begin{tabular}{|c|c|c|c|c|c|c|c|c|}
\hline \multirow[t]{2}{*}{$\begin{array}{l}\text { No. } \\
\text { Spec. }\end{array}$} & \multicolumn{4}{|c|}{ Sambungan I } & \multicolumn{4}{|c|}{ Sambungan $\mathrm{T}$} \\
\hline & $\operatorname{Pr}$ & $\mathrm{Pt}$ & $\mathrm{S}$ & Cp & $\operatorname{Pr}$ & $\mathrm{Pt}$ & $\mathrm{S}$ & $\mathrm{Cp}$ \\
\hline 1 & $\mathrm{~T}$ & A & $\mathrm{T}$ & $\mathrm{T}$ & A & $\mathrm{T}$ & $\mathrm{T}$ & $\mathrm{A}$ \\
\hline 2 & $\mathrm{~T}$ & $\mathrm{~T}$ & $\mathrm{~T}$ & $\mathrm{~T}$ & A & $\mathrm{T}$ & $\mathrm{T}$ & $\mathrm{T}$ \\
\hline 3 & $\mathrm{~A}$ & $\mathrm{~A}$ & $\mathrm{~T}$ & $\mathrm{~A}$ & $\mathrm{~T}$ & $\mathrm{~A}$ & $\mathrm{~T}$ & $\mathrm{~T}$ \\
\hline 4 & A & $\mathrm{T}$ & $\mathrm{T}$ & A & A & A & $\mathrm{T}$ & A \\
\hline
\end{tabular}




\begin{tabular}{|l|l|l|l|l|l|l|l|l|}
\hline 5 & $\mathrm{~T}$ & $\mathrm{~T}$ & $\mathrm{~T}$ & $\mathrm{~T}$ & $\mathrm{~T}$ & $\mathrm{~T}$ & $\mathrm{~T}$ & $\mathrm{~A}$ \\
\hline 6 & $\mathrm{~T}$ & $\mathrm{~A}$ & $\mathrm{~T}$ & $\mathrm{~T}$ & $\mathrm{~T}$ & $\mathrm{~A}$ & $\mathrm{~T}$ & $\mathrm{~T}$ \\
\hline 7 & $\mathrm{~T}$ & $\mathrm{~T}$ & $\mathrm{~A}$ & $\mathrm{~A}$ & $\mathrm{~A}$ & $\mathrm{~A}$ & $\mathrm{~T}$ & $\mathrm{~T}$ \\
\hline 8 & $\mathrm{~T}$ & $\mathrm{~T}$ & $\mathrm{~A}$ & $\mathrm{~A}$ & $\mathrm{~T}$ & $\mathrm{~A}$ & $\mathrm{~T}$ & $\mathrm{~A}$ \\
\hline 9 & $\mathrm{~T}$ & $\mathrm{~T}$ & $\mathrm{~T}$ & $\mathrm{~T}$ & $\mathrm{~T}$ & $\mathrm{~T}$ & $\mathrm{~T}$ & $\mathrm{~A}$ \\
\hline 10 & $\mathrm{~T}$ & $\mathrm{~T}$ & $\mathrm{~T}$ & $\mathrm{~T}$ & $\mathrm{~T}$ & $\mathrm{~T}$ & $\mathrm{~T}$ & $\mathrm{~T}$ \\
\hline 11 & $\mathrm{~T}$ & $\mathrm{~T}$ & $\mathrm{~T}$ & $\mathrm{~T}$ & $\mathrm{~A}$ & $\mathrm{~T}$ & $\mathrm{~A}$ & $\mathrm{~T}$ \\
\hline 12 & $\mathrm{~T}$ & $\mathrm{~T}$ & $\mathrm{~T}$ & $\mathrm{~T}$ & $\mathrm{~T}$ & $\mathrm{~T}$ & $\mathrm{~T}$ & $\mathrm{~A}$ \\
\hline 13 & $\mathrm{~A}$ & $\mathrm{~A}$ & $\mathrm{~A}$ & $\mathrm{~T}$ & $\mathrm{~T}$ & $\mathrm{~T}$ & $\mathrm{~T}$ & $\mathrm{~T}$ \\
\hline 14 & $\mathrm{~T}$ & $\mathrm{~T}$ & $\mathrm{~T}$ & $\mathrm{~T}$ & $\mathrm{~A}$ & $\mathrm{~T}$ & $\mathrm{~T}$ & $\mathrm{~T}$ \\
\hline 15 & $\mathrm{~A}$ & $\mathrm{~T}$ & $\mathrm{~A}$ & $\mathrm{~T}$ & $\mathrm{~T}$ & $\mathrm{~T}$ & $\mathrm{~A}$ & $\mathrm{~A}$ \\
\hline 16 & $\mathrm{~T}$ & $\mathrm{~T}$ & $\mathrm{~T}$ & $\mathrm{~T}$ & $\mathrm{~T}$ & $\mathrm{~T}$ & $\mathrm{~T}$ & $\mathrm{~A}$ \\
\hline 17 & $\mathrm{~A}$ & $\mathrm{~T}$ & $\mathrm{~T}$ & $\mathrm{~T}$ & $\mathrm{~A}$ & $\mathrm{~A}$ & $\mathrm{~T}$ & $\mathrm{~T}$ \\
\hline 18 & $\mathrm{~T}$ & $\mathrm{~T}$ & $\mathrm{~A}$ & $\mathrm{~T}$ & $\mathrm{~T}$ & $\mathrm{~A}$ & $\mathrm{~A}$ & $\mathrm{~T}$ \\
\hline 19 & $\mathrm{~T}$ & $\mathrm{~T}$ & $\mathrm{~T}$ & $\mathrm{~T}$ & $\mathrm{~A}$ & $\mathrm{~T}$ & $\mathrm{~T}$ & $\mathrm{~T}$ \\
\hline 20 & $\mathrm{~T}$ & $\mathrm{~T}$ & $\mathrm{~T}$ & $\mathrm{~T}$ & $\mathrm{~T}$ & $\mathrm{~T}$ & $\mathrm{~T}$ & $\mathrm{~T}$ \\
\hline Jml.Lulus & 15 & 16 & 15 & 16 & 10 & 13 & 16 & 11 \\
\hline$\%$ & 75 & 70 & 75 & 80 & 50 & 65 & 80 & 55 \\
\hline
\end{tabular}

Keterangan :

$\mathrm{T}=$ tidak ada cacat $\quad \mathrm{Pr}=$ Porositas dan retak

$\mathrm{A}=$ ada cacat $\quad \mathrm{Pt}=$ Cacat penetrasi

$$
\begin{aligned}
\mathrm{S} & =\text { slag }(\text { kotoran }) \\
\mathrm{Cp} & =\text { cacat profil }
\end{aligned}
$$

\section{SIMPULAN}

Dari uraian pembahasan tersebut disimpulkan :

\section{Uji Tarik}

Berdasarkan hasil penelitian pengelasan sambungan I dengan menggunakan las busur yang dilaksanakan taruna jurusan teknika, dari 20 specimen yangmemenuhi persyaratan keluusan 12 buah ( $60 \%$ ), sedangkan yang belum memenuhi syarat 8 buah ( $40 \%$ ).

\section{Uji Makro}

Dari Hasil pengujia makro, kualitas benda kerja las busur hasil praktek taruna jurusan teknika untuk sambungan I yang memenuhi syarat kelulusan uji makro sebesar 16 buah (70\%) dan yang tidak lolos dalam persyartan ada 4 buah ( $30 \%$ ). Selanjutnya untuk sambungan $\mathrm{T}$ yang memenuhi syarat kelulusan uji makro sebesar 13 buah ( $65 \%$ ) dan yang tidak memenuhi syarat 7 buah ( $35 \%)$.

\section{DAFTAR PUSTAKA}

Afanasye v. (1977). Siense of Materials, Moscow : MIR,

Didik Surtana, Djaindar Sidabutar Drs. ( 1978 ). Petunjuk Las Asetilin dan Las Listrik,

Departemen Pendidikan dan Kebudayaan

Depdikbud. (1978). Petunjuk Praktek Las Acetyline dan Las Listrik 1,Jakarta

Groendjijk, G and Vanderline,J. (1980). Material Beproeving, Alih bahasa Oleh

Soebandi, S. Pengujian Materi, Jakarta: Bina Cipta, 1984.

Gosse J., Welding Skillls Workbook. (1985). American Technikal Pub., Illinois

Graham E, Maintenance Welding. (1985). Prentice Hall, Englewood Cliffts

Josepeh W, Gianchino. (1976). Welding Skillsand Pratices, American Technical Sociaty, Chicago 
Moch.Alip. (1989). Teori dan Praktek Las, Jakarta,Depdikbud

Smith. F. (1981). Basic Fabrication and Welding Engineering, Hinggong : Wing Tai Cheung Printing co.l.t.d.

Sri Widharto. (1997). Petunjuk Kerja Las, Jakarta: PT. Pradnya Paramita. 